\title{
Hubungan Kecerdasan Emosional dan Motivasi Kerja dengan Kinerja Guru Taman Kanak-Kanak
}

\author{
Dina Ramanda ${ }^{1)^{*}}$, Riswanti Rini ${ }^{1)^{*}}$, Renti Oktaria ${ }^{1)^{*}}$ \\ ${ }^{1}$ FKIP, Universitas Lampung, Jl. Prof. Dr. Sumantri Brojonegoro No. 1 \\ e-mail: ramandadina@gmail.com
}

Abstract. The Relationship of Emotional Intelligence and Work Motivation with The Performance of Kindergarten Teacher. The purpose of this study is to find out the relationship between: 1) emotional intelligence and the performance of kindergarten teachers. 2) motivation of work with the performance of kindergarten teachers. 3) emotional intelligence and motivation of work with the performance of kindergarten teachers. This research uses descriptive correlational method. The population are 82 kindergarten teachers in the Kecamatan Kedamaian. The research sample are 40 teachers with purposive sampling technique. The data collection technique is a questionnaire. The data analysis technique is multiple linear regression. The results showed: 1) There is a relationship between emotional intelligence and the performance of kindergarten teachers, where thitung 3,217> tabel 2,021, a significance of 0.04. 2) There is a relationship between work motivation and kindergarten teacher performance, where thitung 5.090> t tabel 2021, the significance is 0.01. 3) There is a relationship between emotional intelligence and work motivation together with the performance of kindergarten teachers, where $F_{\text {hitung }} 3.526>3.23 F_{\text {tabel }}, 0.04$ significance.

Keywords: emotional intelligence, work motivation, teacher performance

\begin{abstract}
Abstrak. Hubungan Kecerdasan Emosional dan Motivasi Kerja dengan Kinerja Guru Taman Kanak-Kanak. Tujuan penelitian ini adalah mengetahui hubungan antara: 1) Kecerdasan emosional dengan kinerja guru TK. 2) Motivasi kerja dengan kinerja guru TK. 3) Kecerdasan emosional dan motivasi kerja dengan kinerja guru TK. Penelitian ini menggunakan metode deskriptif korelasional. Populasi sebanyak 82 guru TK Kecamatan Kedamaian. Sampel penelitian sebanyak 40 guru dengan teknik pengambilan sampel Purposive Sampling. Teknik pengumpulan data adalah angket. Teknik analisis datanya adalah regresi linier berganda. Hasil penelitian menunjukkan: 1) Terdapat hubungan antara kecerdasan emosional dengan kinerja guru TK, dimana $t$ hitung $3,217>\mathrm{t}$ tabel 2,021, sig 0,04. 2) Terdapat hubungan antara motivasi kerja dengan kinerja guru TK, dimana $t_{\text {hitung }} 5,090>t_{\text {tabel }} 2021$, sig 0,01. 3) Terdapat hubungan antara kecerdasan emosional dan motivasi kerja secara bersama-sama dengan kinerja guru TK, dimana $F_{\text {hitung }}$ $3,526>3,23 \mathrm{~F}_{\text {tabel, }}$ sig 0,04 .
\end{abstract}

Kata Kunci: kecerdasan emosional, motivasi kerja, kinerja guru 


\section{PENDAHULUAN}

Kinerja guru merupakan modal dasar yang diperlukan untuk mencapai tujuan yang dapat dinilai melalui evaluasi kinerja guru, dan tujuannya adalah untuk mendefinisikan setiap pekerjaan yang berhubungan dengan perilaku yang diperlukan untuk pelaksanaannya apakah sesuai dengan indikator yang dipersyaratkan. Kinerja guru sendiri tidak hanya ditunjukkan oleh hasil kerja melainkan ditunjukkan juga oleh perilaku seorang guru dalam bekerja. Kinerja guru yang baik yang ditunjukkan melalui perilaku yakni selalu taat aturan, jujur, mampu bekerja sama dengan tim, memiliki prakarsa, dan memiliki jiwa kepemimpinan yang saling mengayomi. Guru pendidikan anak usia dini menjadi contoh utama yang diambil di lingkungan luar rumah anak. Sikap atau perilaku yang ditampilkannya menjadi cerminan anak nantinya. Penanaman nilai moral, sikap, dan norma menjadi yang utama sebagai pondasi munculnya kompetensikompetensi yang ada pada diri anak. Peningkatan kinerja guru dalam dunia pendidikan perlu dilakukan baik oleh guru sendiri maupun sekolah sebagai instansi bagi wadah seorang guru.

Keberhasilan pendidikan salah satunya dipengaruhi oleh bagaimana kinerja seorang guru. Pekerjaan sebagai guru merupakan pekerjaan yang profesional, karena menjadi seorang guru perlu adanya pendidikan tertentu dan pelatihan yang tinggi. Pendidikan tertentu diperlukan untuk mendapatkan pengetahuan dasar yang mendukung dan menyokong transfer ilmu kepada peserta didik dan pelatihan tinggi diperlukan untuk mengasah keterampilan guru. Penerapan pendidikan dan pelatihan tersebut tentunya akan menunjukkan kualitas kinerja dari seorang guru, dengan kata lain kinerja guru juga dapat ditunjukkan dari seberapa besar guru tersebut memenuhi tuntutan kompetensi- kompetensi yang dipersyaratkan dipenuhi.

Pada kenyataannya kinerja guru saat ini dinilai masih memiliki masalah, diperkuat dengan pernyataan yang ada pada hasil penelitian (Srinalia, 2015) berhubungan dengan rendahnya kinerja guru dikarenakan beberapa masalah diantaranya, masih ada guru yang melanggar tata tertib sekolah dan masalah dalam perencanaan pembelajaran. Rendahnya kualitas guru di Indonesia juga diperkuat oleh hasil penelitian (Kartowagiran, 2011) yang mengemukakan bahwa penyebab kualitas guru di Indonesia masih tergolong relatif rendah antara lain disebabkan oleh tidak terpenuhinya kualifikasi pendidikan minimal yang ditentukan minimal D4 atau S1. Masalah-masalah yang ditemukan dan dibahas tersebut, berkaitan erat dengan berbagai faktor yang mendukung baik dan buruknya kinerja seorang guru. Kinerja yang baik dan bisa menjadi kurang baik ternyata dilatarbelakangi oleh beberapa faktor diantaranya menurut Gibson (2002) mengungkapkan bahwa, "ada tiga kelompok variabel yang mempengaruhi perilaku kerja dan kinerja yaitu: variabel individu, variabel organisasi, dan variable psikologis".

Variabel individu terdiri atas kemampuan dan keterampilan yang menjadi faktor utama yang mempengaruhi kinerja dan merupakan kompetensi kerja yang dimiliki seseorang. Terdapat lima jenis kompetensi yang terkait hal di atas adalah knowledge yakni ilmu yang dimiliki seseorang di dalam bidang yang ditekuni. Skill, adalah kemampuan untuk menunjukkan kinerja yang berhubungan dengan fisik ataupun mental. Self Concep, adalah sikap individu, atau nilai yang dianut. Traits yakni respon yang konsisten terhadap situasi tertentu atau cara seseorang memperlakukan sesuatu. 
Motives adalah tujuan dasar yang mendorong individu untuk bertindak atau melakukan sesuatu. Variabel psikologi, berhubungan erat dengan pandangan, sikap termasuk dalam kepribadian, belajar, dan motivasi. Variabel ini banyak dipengaruhi oleh lingkungan terdekat seseorang seperti keluarga, pengalaman dirinya, dan lingkungan sekitarnya. Kepribadian seseorang memang berbentuk abstrak atau tidak bisa diukur tetapi bisa dilihat dengan bagaimana penampilannya, cara berbicara, ucapan, cara memilih pakaian, dan bagaimana cara memecahkan persoalan dalam kehidupannya. Variabel organisasi, digolongkan kedalam sub variabel sumber dayanya, seperti kepemimpinan, imbalan, struktur, dan desain pekerjaan sesuai dengan tanggung jawab yang diemban.

Dilihat dari variabel individu dan juga variabel psikologis ternyata benar terdapat kecerdasan dan motivasi yang menjadi salah satu faktor penentu apakah baik atau burukkah kinerja seseorang. Utamanya kedua variabel tersebut merupakan faktor yang mempengaruhi kinerja seseorang yang berasal dari dalam diri individu. Menyinggung soal variabel individu dalam hal ini berupa kecerdasan yang dimiliki, merujuk pada salah satu kecerdasan yang berhubungan dengan kesadaran diri, motivasi diri, pengendalian diri, empati, dan keterampilan dalam membina hubungan. Itulah lima unsur dalam kecerdasan emosional yang menentukan posisi seseorang mempelajari keterampilanketerampilan praktis dan merupakan cerminan jiwa seseorang yang akan terlihat dalam kondisi apapun. Emosi tersusun atas energi yang selalu ada di dalam diri seseorang, menggerakkan sejumlah proses mendalam yang mempengaruhi setiap aspek kehidupan. Apabila seseorang meningkatkan kecerdasan emosional yang dimiliki, berarti orang tersebut mengubah wujud energi tersebut, dan akhirnya energi itu akan mempengaruhi seseorang dalam kerja, hidupnya, maupun pergaulannya.

$$
\text { Kecerdasan emosional }
$$

(Emotional Quotient) adalah salah satu kecerdasan yang dimiliki manusia yang memiliki peran penting dalam kesuksesan hidup manusia. Produk dari kecerdasan intelektual merupakan berpikir, yang digunakan sebagai pemecahan masalah. Tetapi, dalam kenyataannya tidak semua persoalaan dan permasalahan dapat dipecahkan dengan pendekatan rasional dalam hal ini produk dari berpikir. Sejatinya, manusia harus memiliki keterampilan dalam mengatur perasaannya seperti mengontrol emosi, mengenali perasaan sendiri dan orang lain, juga mengatur mood atau susasana hati agar bisa menyelaraskannya dengan nalar atau pikiran.

Goleman (2019) Kecerdasan emosional merupakan kemampuan untuk memotivasi diri sendiri, dan bertahan menghadapi situasi yang terpuruk sekalipun, mengendalikan dorongan hati, mengkontrol perasaan dan suasan hati, dan menjaga agar perasaan yang menekan tidak menguasai atau melumpuhkan pikiran. Menurut Uno (2012) kecerdasan emosional adalah kemampuan untuk memotivasi diri sendiri, dan bertahan menghadapi frustasi, mengendalikan dorongan dan tidak melebih-lebihkan kesenanagan, mengatur suasana hati, dan menjaga agar beban stress tidak melumpuhkan kemampuan berpikir, berempati, dan berdoa.

Bukan hanya kecerdasan, variabel lain yang mempengaruhi kinerja seorang guru salah satunya adalah motivasi. Hal ini merupakan bagian dari variabel atau faktor yang mempengaruhi kinerja seseorang. menurut penelitian (Riyadi, 2015) motivasi merupakan salah satu kekuatan yang didapat dari diri maupun 
lingkungan seseorang untuk mencapai suatu tujuan. Sebuah pencapaian tujuan dapat diupayakan dengan sebuah kinerja. Menurut Uno (2012) motivasi kerja merupakan suatu proses yang dilakukan untuk menggerakkan seseorang agar perilaku mereka dapat diarahkan pada upaya-upaya yang nyata untuk mencapai tujuan yang telah ditetapkan dan ia juga mengatakan bahwa motivasi erat hubungannya dengan perilaku dan prestasi kerja. Hal ini memberikan arti bahwa semakin baik motivasi seseorang dalam melakukan pekerjaannya maka semakin baik pula prestasi kerjanya, dan sebaliknya. Motivasi juga dikatakan menurut Sardiman (2007) sebagai serangkaian usaha untuk menyediakan kondisi-kondisi tertentu, sehingga seseorang mau dan ingin melakukan sesuatu, dan bila ia tidak suka, maka akan berusaha untuk meniadakan atau mengelakkan perasaan tidak suka itu. Tujuan dari penelitian ini adalah untuk mengetahui.

1. Mengetahui hubungan antara kecerdasan emosional guru dengan kinerja guru taman kanak-kanak.

2. Mengetahui hubungan antara motivasi kerja dengan kinerja guru taman kanak-kanak.

3. Mengetahui hubungan secara bersama-sama antara kecerdasan emosi dan motivasi kerja guru dengan kinerja guru taman kanakkanak.

Hasil dari penelitian ini adalah memberikan peran dalam pengembangan teori, terutama yang berkaitan dengan faktor-faktor yang mempengaruhi pengembangan kinerja guru. Temuan penelitian ini juga dapat memberikan peran praktis yang berhubungan dengan kecerdasan emosional dan motivasi kerja.

\section{METODE}

$\begin{array}{ccc}\begin{array}{c}\text { Penelitian } \\ \text { menggunakan }\end{array} & \text { ini } & \text { dilakukan } \\ \text { metode } & \text { deskriptif }\end{array}$

korelasional. Penelitian ini tertuju pada sebuah hal yang menggambarkan sesuatu secara apa adanya, sehingga dapat digunakan untuk mengetahui hubungan kecerdasan emosional dan motivasi kerja dengan kinerja guru. Penelitian dilakukan di Taman Kanak-Kanak di Kecamatan Kedamaian, Kota Bandar Lampung yang berjumlah 8 sekolah. Waktu pelaksanaan dilakukan pada tahun ajaran 2019/2020. Subjek penelitian ini adalah seluruh guru taman kanak-kanak di Kecamatan Kedamaian. Teknik pengumpulan data dilakukan dengan cara menggunakan daftar pernyataan atau kuisioner mengenai hal-hal yang berhubungan dengan variabel yang akan diteliti. Analisis data menggunakan uji prasyarat analisis yang terdiri dari uji normalitas dan uji linieritas, juga uji hipotesis yang menggunakan analisis regresi linier berganda. Validitas data, penghitungan menggunakan korelasi product moment antara skor setiap pertanyaan dengan skor total dan pengujiannya dilakukan dengan turun ke lapangan.

\section{HASIL DAN PEMBAHASAN}

\section{Hubungan Kecerdasan Emosional dengan Kinerja Guru Taman Kanak-Kanak}

Berdasarkan analisis data dan pengujian yang telah dilakukan dalam penelitian ini bahwa kecerdasan emosional memiliki hubungan dengan kinerja guru dibuktikan dengan nilai $t_{\text {hitung }}$ $3,217>\mathrm{t}$ tabel 2,021 dengan signifikansi sebesar 0,04, karena nilai signifikansi lebih kecil dari 0,05, maka Ho ditolak dan $\mathrm{Ha}$ diterima.

Hal ini memiliki pengertian bahwa kecerdasan emosional sangat penting diperhatikan dengan sungguhsungguh karena dapat meningkatkan kinerja guru. Secara umum dapat dikatakan bahwa semakin tinggi tingkat kecerdasan emosional maka semakin 
tinggi pula hubungannya dengan kinerja guru taman kanak-kanak. Hal ini mengandung pengertian bahwa guru yang memiliki kecerdasan emosional tinggi dapat diharapkan mampu memotivasi diri jika mengalami penurunan kinerja. Sebagaimana yang diungkapkan oleh Uno (2012) kecerdasan emosional adalah kemampuan untuk memotivasi diri sendiri, dan bertahan menghadapi frustasi, mengendalikan dorongan dan tidak melebih-lebihkan kesenanangan, mengatur suasana hati, dan menjaga agar beban stress tidak melumpuhkan kemampuan berpikir, berempati, dan berdoa. Kecerdasan emosional (Emotional Quotient) adalah salah satu kecerdasan yang dimiliki manusia yang memiliki peran penting dalam kesuksesan hidup manusia. Seorang guru yang memiliki kecerdasan emosional tinggi dapat membantu guru lain yang mengalami kinerja yang rendah dengan begitu akan terbentuk suatu lingkungan yang berkinerja tinggi, dan secara tidak langsung akan kembali menguatkan kinerja mereka.

Kecerdasan emosional merupakan salah satu faktor yang memiliki peran penting dalam upaya meningkatkan kinerja guru. Kondisi kecerdasan emosional yang menurun akan berakibat pada menurunnya kinerja guru dan sebaliknya kondisi kecerdasan emosional yang semakin baik, akan berakibat pada meningkatnya kinerja guru. Hasil penelitian ini berarti relevan dengan konsep-konsep yang dijadikan acuan pada kajian pustaka. Terkait dengan pengaruh kecerdasan emosional terhadap keberhasilan seseorang dikemukakan oleh Bar-On dalam buku Stein dan Book (2002). Menurutnya kecerdasan emosional mempengaruhi kemampuan seseorang untuk berhasil mengatasi tuntutan dan tekanan lingkungan. Bukan hanya itu kecerdasan emosional menuntut seseorang belajar mengakui dan menghargai perasaan pada dirinya dan juga orang lain untuk menanggapi dengan tepat, menerapkan dengan efektif informasi dan energi, emosi dalam kehidupan dan pekerjaan sehari-hari. Bahkan keterampilan kecerdasan emosi bekerja secara sinergis dengan keterampilan kognitif, orang-orang yang berprestasi tinggi memiliki keduanya. Emosi yang lepas kendali dapat membuat orang pandai menjadi bodoh. Tanpa kecerdasan emosi, orang tidak mampu menggunakan kemampuan kognitif mereka sesuai dengan potensi yang maksimum.

\section{Hubungan Motivasi Kinerja dengan Kinerja Guru Taman Kanak-Kanak}

Berdasarkan analisis data dan pengujian yang telah dilakukan dalam penelitian ini bahwa terdapat hubungan antara motivasi kerja dengan kinerja guru dibuktikan dengan nilai $\mathrm{t}_{\text {hitung }} 5,090>\mathrm{t}$ tabel 2021 dengan signifikansi 0,01, karena nilai signifikansi lebih kecil dari 0,05, maka Ho ditolak dan Ha diterima. Hal ini berarti motivasi kerja sangat penting untuk diperhatikan dengan sungguh-sungguh karena dapat meningkatkan kinerja guru.

Secara umum dapat dinyatakan bahwa semakin tinggi tangkat motivasi kerja maka semakin tinggi pula hubungannya dengan kinerja guru taman kanak-kanak. Hal ini mengandung pengertian bahwa guru yang memiliki motivasi kerja tinggi akan berusaha semaksimal mungkin untuk menjadikan dirinya lebih baik dalam bekerja. Kebutuhan menjadi faktor penyebab yang mendasari lahirnya perilaku guru dan memberikan daya dorong yang menggerakkan guru untuk berperilaku kearah tercapainya tujuan organisasi. Jadi motivasi kerja adalah serangkaian usaha dan proses perubahan energi dalam diri yang ditandai dengan munculnya perasaan dorongan dan didahului dengan 
tanggapan yang menggerakkan seseorang mau dan ingin melakukan sesuatu untuk mencapai tujuan.

Hasil penelitian ini jika dikaitkan dengan teori masih relevan, sebagaimana yang dikemukakan oleh Uno (2012) motivasi kerja merupakan suatu proses yang dilakukan untuk menggerakkan seseorang agar perilaku mereka dapat diarahkan pada upaya-upaya yang nyata untuk mencapai tujuan yang telah ditetapkan. Faktor penting yang menyebabkan guru bekerja adalah kebutuhan yang harus dipenuhi. Kebutuhan yang harus dipenuhi tersebut adalah motivasi kerja. Motivasi itu adalah pemberian dorongan dan menimbulkan motif. Dorongan tersebut merupakan gerak jiwa "feeling" dan jasmani untuk berbuat sebagai tanggapan bentuk dorongan agar guru dapat bekerja sesuai dengan tujuan yang telah ditetapkan, maka diperlukan motivasi kerja.

Menurut Sardiman (2007) ada dorongan ketika seseorang melakukan sebuah aktivitas, hal ini berhubungan dengan "biogenic theories" dan "sociogenic theory". "Biogenic theories" berhubungan dengan proses biologis yang menekankan pada mekanisme pembawaan

biologis, seperti insting dan kebutuhankebutuhan biologis. Sedangkan "sosiogenic theories" lebih menekankan adanya pengaruh kebudayaan atau kehidupan masyarakat.

Uno (2012) lebih lanjut mengatakan bahwa motivasi erat hubungannya dengan perilaku dan prestasi kerja. Hal ini memberikan arti bahwa semakin baik motivasi seseorang dalam melakukan pekerjaannya maka semakin baik pula prestasi kerjanya, dan sebaliknya. Bisa diartikan bahwa semakin tinggi motivasi yang dimiliki seorang guru, maka guru tersebut akan semakin tergerak untuk menyelesaikan tugasnya dengan baik otomatis akan berusaha meningkatkan kemampuannya sehingga guru akan meningkatkan kinerja dengan baik.

\section{Hubungan Kecerdasan Emosional dan Motivasi Kerja dengan Kinerja Guru Taman Kanak- Kanak}

Berdasarkan analisis data dan pengujian maka hasil yang diperoleh adalah ada hubungan antara variabel kecerdasan emosional dan motivasi kerja terhadap kinerja guru taman kanak-kanak dilihat dari nilai $F_{\text {hitung }} 3,526>3,23 \mathrm{~F}_{\text {tabel }}$ dengan signifikansi sebesar 0,04. Nilai signifikansi tersebut lebih kecil dari 0,05, maka Ho ditolak dan Ha diterima. Dapat disimpulkan bahwa kedua variabel berhubungan dengan baik.

Hal ini relevan dengan teori yang ada sebagaimana dikemukakan oleh Gibson (2002) yang berbunyi, "ada tiga kelompok variabel yang mempengaruhi perilaku kerja dan kinerja yaitu: variabel individu, variabel organisasi, dan variable psikologis". Gibson mengungkapkan bahwa pada variabel individu terdapat lima jenis kompetensi yang terkait hal di atas adalah knowledge yakni ilmu yang dimiliki seseorang di dalam bidang yang ditekuni. Skill, adalah kemampuan untuk menunjukkan kinerja yang berhubungan dengan fisik ataupun mental. Self Concep, adalah sikap individu, atau nilai yang dianut. Traits yakni respon yang konsisten terhadap situasi tertentu atau cara seseorang memperlakukan sesuatu. Motives adalah tujuan dasar yang mendorong individu untuk bertindak atau melakukan sesuatu. Variabel psikologis berhubungan erat dengan pandangan, sikap termasuk dalam kepribadian, belajar, dan motivasi. Variabel ini banyak dipengaruhi oleh lingkungan terdekat seseorang seperti keluarga, pengalaman dirinya, dan lingkungan sekitarnya. Kepribadian 
seseorang memang berbentuk abstrak atau tidak bisa diukur tetapi bisa dilihat dengan bagaimana penampilannya, cara berbicara, ucapan, cara memilih pakaian, dan bagaimana cara memecahkan persoalan dalam kehidupannya. Dan variabel organisasi digolongkan kedalam sub variabel sumber dayanya, seperti kepemimpinan, imbalan, struktur, dan desain pekerjaan sesuai dengan tanggung jawab yang diemban. Hal ini terlihat jika ada dua variabel yang mempengaruhi kinerja guru yakni variabel individu dan variabel psikologis dimana keduanya berasal dari dalam diri seorang individu.

Kecerdasan emosional dan motivasi kerja cenderung meningkat sejalan dengan aktivitas guru yang berkaitan dengan kinerja dimana guru harus dituntut bekerja secara profesional. Kecerdasan emosional memiliki peran penting pada tempat kerja, disamping juga berperan di lingkungan keluarga, masyarakat, bahkan keadaan emosional seseorang juga membuat jiwa seseorang semakin diperhatikan sehingga memungkinkan dapat menentukan pilihan-pilihan terbaik tentang apa yang akan dikerjakan. Sedangkan motivasi, seseorang yang memiliki motivasi tinggi akan berusaha semaksimal mungkin untuk mencapai prestasi kerja yang lebih baik dengan meningkatkan kemampuan profesionalnya dan keterampilanketerampilan mengajar lainnya sehingga kinerja guru akan meningkat.

\section{SIMPULAN}

Terdapat hubungan antara kecerdasan Emosional dengan kinerja guru taman kanak-kanak. Hal ini ditunjukkan oleh besarnya sumbangan relatif (SR\%) yang diberikan oleh kecerdasan emosional sebesar 50,05\% dan besarnya sumbangan efektif (SE\%) yaitu sebesar 20,08\%. Beberapa hal mengenai kecerdasan emosional yakni kemampuan untuk memotivasi diri sendiri, dan bertahan menghadapi frustasi, mengendalikan dorongan dan tidak melebih-lebihkan kesenanangan, mengatur suasana hati, dan menjaga agar beban stres tidak melumpuhkan kemampuan berpikir, berempati, dan berdoa. Beberapa hal tersebut mempengaruhi kemampuan seseorang mengatasi tuntutan dan tekanan lingkungan dalam hal ini tujuan dari sebuah pekerjaan. Jika seseorang bisa menguasai kemampuan dalam beberapa komponen pada kecerdasan emosional tersebut, maka keberhasilan dalam meningkatkan kinerja atau hasil kerja dengan memotivasi diri sendiri jika mengalami penurunan kinerja bisa terwujud. Kecerdasan emosional menuntut seseorang belajar mengakui dan menghargai perasaan pada dirinya dan juga orang lain untuk menanggapi dengan tepat, menerapkan dengan efektif informasi dan energi, emosi dalam kehidupan dan pekerjaan sehari-hari.

Merujuk pada sumbangan efektif kecerdasan emosional terhadap peningkatan kinerja guru, yaitu sebesar 20,08\% maka dapat diketahui bahwa masih ada $79,92 \%$ faktor lain yang mempengaruhi kinerja guru seperti latar belakang pendidikan, kepemimpinan kepala sekolah, kompensasi, pelatihan kerja, supervisi, lingkungan kerja, dan lainlain.

Terdapat hubungan antara motivasi kerja dengan kinerja guru taman kanakkanak. Hal ini ditunjukkan oleh besarnya sumbangan relatif (SR\%) yang diberikan oleh motivasi kerja sebesar $49,95 \%$ dan besarnya sumbangan efektif (SE\%) yaitu sebesar 20,04\%. Faktor penting yang menyebabkan guru bekerja adalah kebutuhan yang harus dipenuhi. Kebutuhan yang harus dipenuhi tersebut adalah motivasi kerja. Motivasi itu adalah pemberian dorongan dan menimbulkan motif. Semakin tinggi motivasi yang dimiliki seorang guru, 
maka guru tersebut akan semakin tergerak untuk menyelesaikan tugasnya dengan baik otomatis akan berusaha meningkatkan kemampuannya sehingga guru akan meningkatkan kinerja dengan baik.

Merujuk pada sumbangan efektif motivasi kerja terhadap kinerja guru, yaitu sebesar 20,04\% maka dapat diketahui masih ada 79,96\% faktor lain yang mempengaruhi kinerja guru seperti latar belakang pendidikan, kepemimpinan kepala sekolah, kompensasi, pelatihan kerja, supervisi, lingkungan kerja, dan lainlain.

Terdapat hubungan secara bersamasama antara Kecerdasan Emosional dan Motivasi Kerja dengan Kinerja Guru Taman Kanak-Kanak. Secara jelas diterangkan terdapat tiga variabel yang mempengaruhi kinerja seorang guru yakni variabel individu, variabel psikologi, dan variabel organisasi. Terdapat dua variabel yang kuat mempengaruhi kinerja seseorang yakni variabel individu dan variabel psiokologi yang didalamnya jelas tertulis bahwa kinerja seseorang dipengaruhi oleh berbagai faktor beberapa diantaranya yakni kemampuan untuk menunjukkan suatu kinerja, sikap seorang individu terhadap lingkungannya, dan tujuan dasar yang mendorong seseorang untuk bertindak atau motivasi. Jadi terdapat hubungan antara kecerdasan emosional dan motivasi kerja dengan kinerja seseorang.

Kinerja guru ditentukan oleh kontribusi kecerdasan emosional dan motivasi kerja secara bersama-sama sebesar $40,12 \%$, sedangkan sisanya sebesar $59,88 \%$ dipengaruhi oleh faktor lain yang tidak dimasukkan dalam penelitian yang dapat berupa latar belakang pendidikan, kepemimpinan kepala sekolah, kompensasi, pelatihan kerja, supervisi, lingkungan kerja, dan lain-lain.

\section{REFERENSI}

Gibson. (2002). Organisasi Perilaku struktur proses Terjemahan $V$. Jakarta: Erlangga.

Goleman, D. (2019). Emotional Intelligence Kecerdasan Emosional Mengapa EL Lebih Penting daripada IQ. Jakarta: PT Gramedia Pustaka Utama.

Kartowagiran, B. (2011). Kinerja Guru Profesional (Guru Pasca Sertifikasi). Jurnal Universitas Negeri Yogyakarta. 3: 463-473.

Riyadi, S. (2015). Effect of Work Motivation, Work Stress and Job Satisfaction on Teacher Performance at Senior High School (SMA) Throughout The State Central Tapanuli, Sumatra. Journal Of Humanities And Social Science. 20: 52-57.

Sardiman. (2007). Interaksi dan Motivasi Belajar Mengajar. Jakarta: PT RajaGrafindo Persada.

Srinalia. (2015). Faktor-Faktor Penyebab Rendahnya Kinerja Guru dan Korelasinya terhadap Pembinaan Siswa: Studi Kasus di SMAN 1 Darul Imarah Aceh Besar. Jurnal Ilmiah Didaktika. 15: 193-207.

Stein, S.J., Book, H.E. (2002). Ledakan EQ 15 Prinsip Dasar Kecerdasan Emosional meraih sukses. Bandung: Kaifa.

Uno, H. B. (2012). Orientasi Baru dalam Psikologi Pembelajaran. Jakarta: PT Bumi Aksara. . (2012). Profesi Kependidikan Problema, Solusi, dan Reformasi Pendidikan di Indonesia. Jakarta: PT Bumi Aksara. (2012). Teori Motivasi \& Pengukurannya Analisis di Bidang Pendidikan. Jakarta: PT Bumi Aksara. 